\title{
ODNOS PETFAKTORSKOG MODELA LIČNOSTI I ŠKOLSKOG USPJEHA KOD UČENIKA SREDNJIH ŠKOLA
}

\author{
Doris Matošić \\ Kineziološki fakultet Sveučilišta u Splitu, Sveučilište u Splitu, Republika Hrvatska
}

\begin{abstract}
Sažetak
Cilj je istraživanja bio utvrditi odnos između petofaktorskog modela ličnosti i uspjeha u školi i vladanja u dvjema vremenskim točkama; na početku 3. (T1) i na kraju 4. razreda srednje škole (T2). U istraživanju je sudjelovalo 421 učenika srednje škole u dobi od 16 do 19 godina. Za ispitivanje dimenzija ličnosti korištena je adaptirana verzija Petofaktorskog inventara ličnosti. Školski uspjeh mjeren je ocjenom općeg uspjeha na kraju školske godine, a ocjena vladanja mjerila se na temelju neopravdanih sati. Glavna analiza podataka uključivala je dvije hijerarhijske regresijske analize u svakoj vremenskoj točki. U oba mjerenja rod je značajno doprinio objašnjenju uspjeha u školi i vladanja. Konkretno, učenice su pokazale bolji uspjeh u školi te bolje vladanje u usporedbi s učenicima. Nadalje, u prvome mjerenju, osobe s izraženim dimenzijama ličnosti i otvorenosti prema iskustvu, savjesnosti te manje izraženim neuroticizmom pokazale su bolji uspjeh u školi u usporedi s osobama s manje izraženom otvorenosti prema iskustvu, savjesnosti te više izraženim neuroticizmom. Međutim, petofaktorske dimenzije ličnosti u drugom mjerenju nisu značajno dodatno objasnile uspjeh u školi i vladanje. Rezultati ističu utjecaj pojedinih osobina ličnosti na opći uspjeh i vladanje u srednjoj školi u dvama mjerenjima.
\end{abstract}

Ključne riječi: obrazovanje, osobine ličnosti, školski uspjeh, učenici, vladanje

\section{UvoD}

Školski uspjeh i ocjena vladanja, kao mjerila uspjeha u obrazovanju, mogu imati važnu ulogu u životu pojedinca. Školski uspjeh uz vladanje, kao ocjenu za ponašanje, još od osnovne škole jedni su od glavnih čimbenika o kojem ovise brojni životni događaji, od upisa u srednju školu, odabira zanimanja, odlaska na daljnje školovanje te mogućnosti zapošljavanja. Cjelokupno postignuće učenika u školama određeno je ocjenama uspjeha iz različitih predmeta te ocjenom vladanja koja se, među ostalim, mjeri njegovim odnosom prema radu (i.e., pohađanjem nastave) i drugim učenicima i učiteljima. Različiti su čimbenici koji mogu utjecati na školski uspjeh pojedinaca, od obilježja obitelji, socijalne okoline, do osobina ličnosti (Barbarović, Burušić i Šakić, 2010). Jedno od ključnih pitanja istraživačkih studija u području obrazovanja upravo je utjecaj osobina ličnosti na cjelokupni uspjeh učenika (Barbarović i sur., 2010).

Ličnost je skup relativno trajnih psihičkih osobina pojedinca važnih u razumijevanju $\mathrm{i}$ predviđanju ponašanja pojedinaca u okolini (Larsen i Buss, 2008). Osobine ličnosti mogu objasniti načine i razloge na koji se pojedinici ponašaju, osjećaju i misle (Pervin, Cervone, i John, 2008). Najčešće korišten model ličnosti u psihologiji ličnosti, koji se zasniva na leksičkom pristupu, je petodimenzionalna taksonomija ličnosti, to jest petofaktorski model ličnosti (Mlačić, 2002; Pervin i sur., 2008). Prema navedenom modelu razlikujemo pet faktora ličnosti, a to su ekstraverzija, ugodnost, savjesnost, neuroticizam i otvorenost prema iskustvu (Pervin i sur., 2008). 
Ekstraverzija je crta ličnosti koja se odnosi na međuljudske odnose. Osobe s izraženom ekstraverzijom vole biti u socijalnoj interakciji, stjecati prijatelje te doživljavaju pozitivnije emocije intenzivnije od osoba koji su introvertirani (Ashton, Lee, i Paunone, 2002; Pervin i sur., 2008). Ugodnost je dimenzija koja se odnosi na osobine kao iskrenost, razumijevanje, toplina u međuljudskim odnosima. Osobe koje imaju izraženu tu osobinu ličnosti dobro se slažu s drugima, suradljivi su, altruistični i empatični za razliku od osoba koji nemaju izraženu onavedenu osobinu ličnosti (Larsen i Buss, 2008). Savjesnost je osobina ličnosti koja karakterizira pojedince koji se vode ciljevima, točni su, pouzdani i radišni (Larsen i Buss, 2008). Neuroticizam je dimenzija koja se odnosi na emocionalnu stablinost. Osobe s izraženim neuroticizmom anksiozne su, nesigurne i mrzovoljne u usporedbi s osobama koje imaju niže izraženi neuroticizam (Gračanin, Kardum, i Krapić, 2004). Na kraju, otvorenost prema iskustvu uključuje otvoreni duh, radoznalost te otvorenost novim idejama za osobe koje imaju izraženu navedenu osobinu (Larsen i Buss, 2008).

Brojna istraživanja ispitala su utjecaj pet faktora modela ličnosti na uspjeh u školi (metaanaliza; Poropat, 2009) i pokazala nedosljedne rezultate zbog čega su daljnja ispitivanja neophodna. Najdosljedniji rezultati pokazali su se kod povezanosti osobine ličnosti savjesnosti i općeg uspjeha u školi (Chamorro - Premuzic i Furnham, 2003; Ivić i Matešić, 2009; Matešić, Ružići Matešić, 2009; Vrdoljak, Lovaković i Kurtović, 2018). U navedenim istraživanjima savjesnost se pokazala kao najboljim prediktorom školskog uspjeha kod učenika srednjih škola. Učenici srednjih škola koji su imali izražene karakteristike savjesnosti, kao točnost, pouzdanost i radišnost, pokazali su bolji opći uspjeh u usporedbi s učenicima s manje izraženom tom osobinom. Uz savjesnost, otvorenost prema iskustvu najčeće se povezuje sa školskim uspjehom (Poropat, 2009). Pojedina istraživanja pokazala su pozitivnu povezanost otvorenosti prema iskustvu i uspjeha u školi (Ivić i Matešić, 2009; Vrdoljak i sur., 2018), što znači da učenici koji su radoznali i otvoreni prema novim idejama najčešće postižu veći uspjeh.

Pojedina su istraživanja pokazala negativnu povezanost između neuroticizma i uspjeha u školi (Chamorro-Premuzic i Furnham, 2003; Mlačić i sur., 2009). Osobe s povišenim neuroticizmom mogu biti anksiozne, nesigurne i zabrinute i, zbog nemogućnosti nošenja sa stresom, pokazuju slabiji uspjeh u školi u usporedbi s osobama s nižim neuroticizmom (Chamorro - Premuzic, 2007). Konačno, nedosljeni rezultati pokazali su se u ispitivanju povezanosti ekstraverzije i ugodnosti s uspjehom u školi (Poropat, 2009). Postoje dokazi u pojedinim istraživanjima o pozitivnoj i negativnoj povezanosti navedenih osobina ličnosti s uspjehom u školi (Poropat, 2009). Na primjer, studije ispitane na srednjoškolcima pokazale su negativnu povezanost ugodnosti i uspjeha u školi (Matešić i sur., 2009) te ekstraverzije i uspjeha u školi (Čuljak i Mlačić, 2014), dok su studije ispitane na osnovnoškolcima pokazale pozitivnu povezanost (Poropat, 2009). Negativna povezanost kod srednjoškolaca može se objasniti željom učenika u toj dobi za samostalnošću, socijalnim razvojem i druženjem s prijateljima, što može dovesti do nedostatka vremena i motivacije za učenjem.

U skladu s navedenim, cilj je provedenog istraživanja bio ispitati povezanost petofaktorskog modela ličnosti i uspjeha u školi mjerenog općim uspjehom i vladanjem srednjoškolaca u dvjema vremenskim točkama (na početku 3. i na kraju 4.razreda srednje škole). Prijašnje studije istaknule su važnost doprinosa osobina ličnosti školskom uspjehu u nižim razredima srednje škole, u usporedbi s višim razredima srednje škole koje se više temelji na iskustvu i razvijenim vještinama (Peterson i Whiteman, 2007; Caprara, Vecchione, Alessandri, Gerbino i Barbaranelli, 2011). U skladu s navedenim možemo pretpostaviti da će savjesnost i otvorenost prema iskustvu biti pozitivni prediktori školskog uspjeha i vladanja, a ugodnost, ekstraverzija i neuroticizam bit će negativni prediktori kriterijskih varijabli u prvoj vremenskoj točki, dok u drugoj točki mjerenja doprinosa osobina ličnosti školskom uspjehu i vladanju neće biti. S obzirom na dokazanu razliku uspjeha u školi između učenika i učenica (Koludrović i Reić-Ercegovac, 2013), možemo pretpostaviti da će postojati razlika između učenika i učenica kod obiju kriterijskih varijabli. 


\section{Metoda}

\section{Uzorak}

U istraživanju je sudjelovao 421 srednjoškolac, od toga 200 učenica i 217 učenika (4 učenika nisu odgovorila na pitanje o rodu) četverogodišnjih programa srednjih strukovnih škola (349 učenica i učenika) i gimnazija (72 učenice i učenika) šireg područja Tuzle (i.e., Tuzlanskog kantona) iz Bosne i Hercegovine. Srednjoškolci su u prosjeku imali 17 godina ( $M_{\text {godina }}=17.33, S D$ $=.50$, raspon godina od 16 do 19) uključujući mjerenje u objema vremenskim točkama.

\section{Instrumenti}

Faktori ličnosti. Za ispitivanje osobina ličnosti korištena je adaptirana verzija Petofaktorskog inventara ličnosti (i.e., Big Five Inventory; John, Donahue i Kentle, 1991) prevedena za istraživačke svrhe u Bosni i Hercegovini (Vardo i Efendić-Spahić, 2016). BFI uključuje 44 čestice i sastoji se od pet subskala, tj. pet dimenzija ličnosti, a to su: ekstraverzija (8 čestica), savjesnost (9 čestica), ugodnost ( 9 čestica), neuroticizam ( 8 čestica) i otvorenost (10 čestica). Upitnik se temelji na samoprocjeni (e.g., "Ja sam osoba koja mnogo brine.", „Ja sam osoba koja obavlja poslove pravovremeno.") i čestice su prikazane u obliku kratkih rečenica koje mjere dimenzije ličnosti opisane prema John-u (1990). Procjena se izračunava na Likertovoj skali od 1 do 5, pri čemu 1 označava potpuno neslaganje („uopće se ne slažem“), a 5 potpuno slaganje („potpuno se slažem"). Rezultat na pojedinoj subskali izračunava se zbrojem odgovora na česticama pojedine subskale. Instrument je pokazao dobre psihometrijske karakteristike na uzorcima ispitanika iz SAD-a i Kanade ( $\alpha=.75$ do $\alpha=.90$ : John i sur., 1991) te prihvatljivu pouzdanost na uzorku ispitanika iz Bosne i Hercegovine (Efendić-Spahić i Vardo, 2017; Vardo i Efendić-Spahić, 2016). Instrument je u ovom istraživanju pokazao dobru pouzdanost, mjerenu alfa koeficijentom, $\alpha=.81$ u prvoj vremenskoj točki i $\alpha=.82$ u drugoj vremenskoj točki.

Uspjeh u školi i vladanje. Uspjeh u školi mjerio se pitanjem o ukupnom općem uspjehu na kraju školske godine (i.e., odličan, vrlo dobar, dobar, dovoljan i nedovoljan). Vladanje se mjerilo pitanjem o ocjeni vladanja na kraju školske godine (i.e., primjereno, vrlo dobro, dobro, zadovoljava, loše). Ocjene iz vladanja izriču su prema Pravilniku o povredama discipline ... $i$ posljedičnom odnosu na ocjenu iz vladanja učenika u Bosni i Hercegovini (2014), uglavnom na osnovi neopravdanih izostanaka (veći broj neopravdanih izostanaka rezultira manjom ocjenom vladanja).

\section{Postupak}

Ispitivanje je provedeno $\mathrm{u}$ dvjmae fazama, $\mathrm{tj}$. dvjema vremenskim točkama, na početku 3. razreda (T1) i na kraju 4. razreda srednje škole (T2), na istom uzorku učenika. Učenici su bili ispitani postupkom anketiranja. Učenici su samostalno ispunjavali upitnik koji je sadržavao pitanja o osobinama ličnosti, općem uspjehu u školi i ocjeni vladanja koristeći metodu papir olovka. Istraživanje je provedeno za vrijeme školske nastave u školskim prostorijama. Istraživanje je bilo anonimno i dobrovoljno i ispitanici su dobili usmenu uputu za rad prije samog početka ispunjavanja upitnika.

\section{Obrada podataka}

Na kraju cjelokupnog istraživanja 436 učenika ispunilo je ankete. Od toga, jedna je učenik ispitan samo u prvoj vremenskoj točki, 11 učenika ispitano je samo u drugoj vremenskoj točki, a toje učenika nije odgovorilo ni na jedno pitanje o dimenzijama ličnosti u obama mjerenjima. Navedeni učenici nisu uračunati u analizu te je završni uzorak brojio 421 učenicu i 
učenika srednjih škola. Za obradu podataka korišten je statistički program SPSS. Provedena je deskriptivna analiza i korelacije svih varijabli te dvije hijerahijske regresijske analize u svakoj vremenskoj točki.

\section{RezULtatI}

\section{Deskriptivna analiza i korelacije}

Deskriptivni parametri (prosječne vrijednosti, standardne devijacije, rasponi) i korelacije svih varijabli prikazane su u Tablicama 1 . i 2 . U prvoj vremenskoj točki prosječne vrijednosti uspjeha u školi te ocjena vladanja pokazale su se visoke. Aritmetičke sredine osobina ličnosti savjesnosti, ugodnosti te otvorenosti prema iskustvu ukazuju na prosječne procjene sudionika na tim skalama, dok osobine ličnosti ekstraverzije i neuroticizma ukazuju na nešto niže procjene sudionika u odnosu s ostalim osobinama ličnosti. Rezultati su prikazani u Tablici 1.

Tablica 1. Deskriptivna analiza i korelacije uspjeha u školi, vladanja i pet dimenzija ličnosti u $\mathrm{T} 1(\mathrm{~N}=421)$

\begin{tabular}{|c|l|c|c|c|c|c|c|c|}
\hline & Varijable & 1 & 2 & 3 & 4 & 5 & 6 & 7 \\
\hline 1 & Uspjeh u školi & - & & & & & & \\
\hline 2 & Vladanje & $.36^{* *}$ & - & & & & & \\
\hline 3 & Ekstraverzija & .03 & $.17^{* *}$ & - & & & & \\
\hline 4 & Savjesnost & .08 & $.13^{* *}$ & $.46^{* *}$ & - & & & \\
\hline 5 & Ugodnost & -.05 & $.12^{*}$ & $.54^{* *}$ & $.53^{* *}$ & - & & \\
\hline 6 & Neuroticizam & -.03 & $.13^{* *}$ & $.47^{* *}$ & $.51^{* *}$ & $.54^{* *}$ & - & \\
\hline 7 & Otvorenost & $.12^{*}$ & $.10^{*}$ & $.56^{* *}$ & $.44^{* *}$ & $.42^{* *}$ & $.39 * *$ & - \\
\hline & Raspon & $1-5$ & $1-5$ & $1-40$ & $1-45$ & $1-45$ & $1-40$ & $1-50$ \\
\hline & $M$ & 4.07 & 4.79 & 28.85 & 31.18 & 31.48 & 26.98 & 34.14 \\
\hline & $S D$ & .94 & .58 & 4.40 & 4.49 & 4.25 & 4.35 & 6.58 \\
\hline
\end{tabular}

Napomena: $M$ - prosjek, $S D$ - standardna devijacija. Korelacijske vrijednosti prikazane su ispod dijagonale. ${ }^{*} p<.05, * * p<.01$

Za izračunavanje povezanosti korišteni su Pearsonovi koeficijenti korelacije, a rezultati za prvu vremesku točku prikazani su u Tablici 1 . Koeficijenti korelacije pokazali su statistički značajnu umjerenu pozitivnu povezanost uspjeha u školi i vladanja te nisku značajnu povezanost uspjeha u školi i otvorenosti prema iskustvu. Uspjeh u školi nije pokazao statistički značajnu povezanost s ostalim osobinama ličnosti. Varijabla vladanje pokazala je nisku, statistički značajnu pozitivnu povezanost s ekstraverzijom, savjesnošću, ugodnosti, neuroticizmom i otvorenosti prema iskustvu. Koeficijenti korelacije između svih osobina ličnosti mjerenih u istraživanju međusobno su pokazali umjerenu do visoku statistički značajnu pozitivnu povezanost.

$U$ drugoj vremenskoj točki prosječne vrijednosti uspjeha u školi bile su nešto više od prvog mjerenja, dok je ocjena vladanja bila nešto niža u odnosu na prvu vremensku točku. Aritmetičke sredine osobina ličnosti savjesnosti, ugodnosti te otvorenosti prema iskustvu ukazuju na prosječne procjene sudionika na tim skalama, dok osobine ličnosti ekstraverzije i neutroticizma ukazuju na nešto niže procjene sudionika u odnosu s ostalim osobinama ličnosti. Rezultati su prikazani u Tablici 2. 
Tablica 2. Deskriptivna analiza i korelacije uspjeha u školi, vladanja i pet dimenzija ličnosti u $\mathrm{T} 2(\mathrm{~N}=421)$

\begin{tabular}{|c|l|c|c|c|c|c|c|c|}
\hline & Varijable & 1 & \multicolumn{1}{c|}{2} & \multicolumn{1}{c|}{3} & 4 & 5 & 6 & 7 \\
\hline 1 & Uspjeh u školi & - & & & & & & \\
\hline 2 & Vladanje & $.38^{* *}$ & - & & & & & \\
\hline 3 & Ekstraverzija & .01 & .04 & - & & & & \\
\hline 4 & Savjesnost & .05 & .09 & $.52^{* *}$ & - & & & \\
\hline 5 & Ugodnost & .00 & .01 & $.60^{* *}$ & $.51^{* *}$ & - & & \\
\hline 6 & Neuroticizam & .02 & .10 & $.45^{* *}$ & $.51^{* *}$ & $.46^{* *}$ & - & \\
\hline 7 & Otvorenost & .05 & .02 & $.60^{* *}$ & $.45^{* *}$ & $.47^{* *}$ & $.39 * *$ & - \\
\hline & Raspon & $1-5$ & $1-5$ & $1-40$ & $1-45$ & $1-45$ & $1-40$ & $1-50$ \\
\hline & $M$ & 4.12 & 4.69 & 28.71 & 30.88 & 30.86 & 26.48 & 34.35 \\
\hline & $S D$ & .85 & .76 & 4.26 & 4.57 & 4.39 & 4.39 & 6.63 \\
\hline
\end{tabular}

Napomena: ${ }^{*} p<.05, * * p<.01$

Za izračunavanje povezanosti korišteni su Pearsonovi koeficijenti korelacije, a rezultati za drugu vremensku točku prikazani su u Tablici 2. Koeficijenti korelacije pokazali su statistički značajnu umjerenu pozitivnu povezanost uspjeha u školi i vladanja. U drugoj vremenskoj točki uspjeh u školi i vladanje nisu pokazali statistički značajnu povezanost ni s jednom osobinom ličnosti. Koeficijenti korelacije između svih osobina ličnosti mjerenih u istraživanju međusobno su pokazali umjerenu do visoku statistički značajnu pozitivnu povezanost. Varijable faktora ličnosti u prvoj vremenskoj točki zadovoljavaju pretpostavke normalne distribucije (asimetričnost: -.851 do -.407 i kurtičnost (spljoštenost): .554 do 3.117; Tablica 1) kao i varijable faktora ličnosti u drugoj vremenskoj točki (asimetričnost: -.756 do -.052 i kurtičnost (spljoštenost): .475 do 2.479; Tablica 2).

\section{Hijerarhijska regresijska analiza T1}

Tablica 3. prikazuje rezultate dviju hijerarhijskih regresijskih analiza u prvoj vremenskoj točki u dva koraka. U prvoj hijerarhijskoj analizi kao kriterijska varijabla korišten je uspjeh u školi, a kao prediktorske varijable rod i osobine ličnosti. Prvi je korak pokazao statistički značajnu razliku roda i uspjeha u školi $(F(1,413)=13.55, p<.01)$, objašnjavajući $3 \%$ varijance. Efekt roda bio je $\beta=.18, p<.01$, što znači da su učenice u ovom uzorku pokazale bolji uspjeh u školi od učenika $\left(M_{\text {uspjeh učenice }}=4.26, M_{\text {uspjeh učenici }}=3.93\right)$. Drugi je korak pokazao statistički značajnu razliku između roda i pet dimenzija ličnosti i uspjeha u školi $(F(5,408)=3.61, p<.01)$, objašnjavajući $4 \%$ dodatne varijance. Efekt roda bio je $\beta=.21, p<.01$, što znači da su učenice $u$ ovom uzorku pokazale bolji uspjeh u školi od učenika ( $M_{\text {uspjeh učenice }}=4.26, M_{\text {uspjeh učenici }}=3.93$ ). Isto tako, statistički značajni bili su i efekti otvorenosti $(\beta=.15, p<.05)$, savjesnosti $(\beta=.14, p<$ $.05)$ te neuroticizma $(\beta=-.15, p<.05)$, što znači da su osobe $s$ izraženom otvorenosti prema iskustvu, savjesnosti te manjim neuroticizmom pokazale bolji uspjeh u školi od osoba s manje izraženom otvorenosti prema iskustvu i savjesnosti te više izraženim neuroticizmom. 
Tablica 3. Hijerarhijska regresijska analiza povezanosti roda i pet dimenzija ličnosti kao prediktora s uspjehom u školi i vladanjem kao kriterija u T1

\begin{tabular}{|c|c|c|}
\hline $\begin{array}{l}\text { Prediktorske } \\
\text { varijable }\end{array}$ & $\begin{array}{c}\text { Uspjeh u školi } \\
\text { T1 }\end{array}$ & $\begin{array}{c}\text { Vladanje } \\
\text { T1 }\end{array}$ \\
\hline \multicolumn{3}{|c|}{ 1. korak } \\
\hline Rod & $.18^{* *}$ & $.20 * *$ \\
\hline$\Delta \mathrm{R}^{2}$ & .03 & .04 \\
\hline $\mathrm{R}^{2}$ & .03 & .04 \\
\hline Adjusted $\mathrm{R}^{2}$ & .03 & .04 \\
\hline$F(1,413)$ & $13.55^{* *}$ & \\
\hline$F(1,415)$ & & $17.42^{* *}$ \\
\hline \multicolumn{3}{|c|}{ 2. korak } \\
\hline Rod & $.21 * *$ & $.18^{* *}$ \\
\hline Otvorenost & $.15^{*}$ & -.01 \\
\hline Savjesnost & $.14^{*}$ & .07 \\
\hline Neuroticizam & $-.15 *$ & -.01 \\
\hline Ekstraverzija & -.04 & .08 \\
\hline Ugodnost & -.10 & .04 \\
\hline$\Delta R^{2}$ & .04 & .02 \\
\hline $\mathrm{R}^{2}$ & .07 & .06 \\
\hline Adjusted $\mathrm{R}^{2}$ & .06 & .05 \\
\hline$F(5,408)$ & $3.61 * *$ & \\
\hline$F(5,410)$ & & 1.95 \\
\hline
\end{tabular}

U drugoj hijerarhijskoj analizi kao kriterijska varijabla korišteno je vladanje, a kao prediktorske varijable rod i osobine ličnosti. Prvi je korak pokazao statistički značajnu razliku roda i vladanja $(F(1,415)=17.42, p<.01)$, objašnjavajući $4 \%$ varijance. Efekt roda bio je $\beta=.20$, $p<.01$, što znači da su učenice u ovom uzorku pokazale bolje vladanje od učenika $\left(M_{\text {vladanje učenice }}\right.$ $\left.=4.92, M_{\text {vladanje učenici }}=4.68\right)$. lako je u drugom koraku statistički značajna razlika između roda $\mathrm{i}$ vladanja ostala prisutna, drugi se korak nije pokazao statistički značajnim $(F(5,410)=1.95$, $p=.09$ ). Osobine ličnosti nisu se pokazale kao statistički značajni faktori koji utječu na ocjenu vladanja učenika.

\section{Hijerarhijska regresijska analiza T2}

Tablica 4. prikazuje rezultate dviju hijerarhijskih regresijskih analiza u drugoj vremenskoj točki u dva koraka. U prvoj hijerarhijskoj analizi kao kriterijska varijabla korišten je uspjeh u školi, a kao prediktorske varijable rod i osobine ličnosti. Prvi je korak pokazao statistički značajnu razliku roda i uspjeha u školi $(F(1,414)=18.85, p<.01)$, objašnjavajući $4 \%$ varijance. Efekt roda bio je $\beta=.21, p<.01$, što znači da su učenice u ovom uzorku pokazale bolji uspjeh u školi od učenika $\left(M_{\text {uspjeh učenice }}=4.31, M_{\text {uspjeh učenici }}=3.96\right)$. Drugi se korak nije pokazao statistički značajnim $(F(5,409)=.56, p=.73)$. lako je u drugom koraku statistički značajna razlika između 
roda i uspjeha u školi ostala prisutna, osobine ličnosti nisu se pokazale kao statistički značajni faktori koji utječu na uspjeh u školi.

Tablica 4. Hijerarhijska regresijska analiza povezanosti roda i pet dimenzija ličnosti kao predikotra s uspjehom u školi i vladanjem kao kriterija u T2

\begin{tabular}{|l|c|c|}
\hline \multicolumn{1}{|c|}{$\begin{array}{c}\text { Prediktorske } \\
\text { varijable }\end{array}$} & $\begin{array}{c}\text { Uspjeh u školi } \\
\text { T2 }\end{array}$ & $\begin{array}{c}\text { Vladanje } \\
\text { T2 }\end{array}$ \\
\hline \multicolumn{2}{|c|}{1. korak } \\
\hline Rod & $.21^{* *}$ & $.14^{* *}$ \\
\hline$\Delta \mathrm{R}^{2}$ & .04 & .02 \\
\hline $\mathrm{R}^{2}$ & .04 & .02 \\
\hline Adjust ed $\mathrm{R}^{2}$ & .04 & .02 \\
\hline $\mathrm{F}(1,414)$ & $18.85^{* *}$ & $7.67^{* *}$ \\
\hline $\mathrm{F}(1,414)$ & & $.12^{*}$ \\
\hline & 2. korak & -.02 \\
\hline Rod & $.22^{* *}$ & .09 \\
\hline Otvorenost & .08 & .06 \\
\hline Savjesnost & .05 & .02 \\
\hline Neuroticizam & -.03 & .09 \\
\hline Ekstraverzija & -.02 & .01 \\
\hline Ugodnost & -.06 & .03 \\
\hline$\Delta \mathrm{R}^{2}$ & .01 & .02 \\
\hline $\mathrm{R}^{2}$ & .05 & 1.06 \\
\hline Adjusted $\mathrm{R}^{2}$ & .04 & \\
\hline $\mathrm{F}(5,409)$ & .56 & \\
\hline $\mathrm{F}(5,409)$ & & \\
\hline
\end{tabular}

Napomena: ${ }^{*} p<.05,{ }^{* *} p<.01$

U drugoj hijerarhijskoj analizi kao kriterijska varijabla korišteno je vladanje, a kao prediktorske varijable rod i osobine ličnosti. Prvi je korak pokazao statistički značajnu razliku roda $\mathrm{i}$ vladanja $(F(1,414)=7.67, p<.01)$, objašnjavajući $2 \%$ varijance. Efekt roda bio je $\beta=.14, p<.01$, što znači da su učenice u ovom uzorku pokazale bolje vladanje od učenika ( $M_{\text {vladanje učenice }}=4.81$, $\left.M_{\text {vladanje učenici }}=4.60\right)$. lako je u drugom koraku statistički značajna razlika između roda i vladanja ostala prisutna, drugi korak nije se pokazao statistički značajnim $(F(5,409)=1.06, p=.38)$. Osobine ličnosti nisu se pokazale kao statistički značajni faktori koji utječu na ocjenu vladanja učenika.

\section{RASPRAVA}

Rezultati istraživanja za obje vremenske točke pokazali su razliku roda i uspjeha u školi i vladanju. Učenice su u ovom uzorku pokazale bolji uspjeh u školi i vladanju u usporedbi s uče- 
nicima. Ovaj nalaz u skladu je s prijašnjim istraživanjima koja potvrđuju bolji opći prosjek učenica srednjih škola u usporedbi s učenicima (Koludrović i Reić-Ercegovac, 2013).

Kod povezanosti osobina ličnosti i uspjeha u školi u prvoj vremenskoj točki, rezultati su pokazali savjesnost i otvorenost prema iskustvu kao značajne pozitivne prediktore uspjeha u školi te neuroticizam kao značajan negativni prediktor uspjeha u školi. U skladu s nalazima prijašnjih istraživanja (Chamorro - Premuzic i Furnham, 2003; Ivić i Matešić, 2009; Matešić, i sur., 2009) savjesnost se pokazala kao značajna dimenzija ličnosti pozitivno povezana s uspjehom u školi. Učenici koji imaju izražene karakteristike savjesnosti kao pouzdanost, odgovornost, radišnost te težnju vlastitim ciljevima, postići će bolji opći uspjeh u školi od onih koji nemaju izraženu tu osobinu. Navedeni rezultati mogu se generalizirati i izvan okvira samog školskog uspjeha. Istraživanja su pokazala da je savjesnost karakteristika koja pridnosi uspjehu u poslu ili u sportu (Čuljak, Markota i Kovačević, 2010).

Nadalje, u skladu s prijašnjim istraživanjima (Chamorro - Premuzic, 2007), neuroticizam se pokazao kao značajna osobina ličnosti negativno povezana s uspjehom u školi. Učenici koji imaju izražene karakteristike neuroticizma, kao anksioznost, nervoza, tuga, postići će lošiji uspjeh u školi od onih koji nemaju izraženu tu osobinu. Takav je rezultat očekivan s obzirom da se radi o adolescentnoj skupini ispitanika koji su u dobi razvoja kada se susreću s brojim životnim stresorima i stoga su češće izloženi situacijama koje izazivaju anksioznost i zabrinutost, što im može izazivati poteškoće u učenju i školskom uspjehu (Seiffge - Krenke, 2000).

U skladu s pojedinim istraživanjima (Ivić i Matešić, 2009), otvorenost prema iskustvu pokazala se kao značajna osobina ličnosti pozitivno povezana s uspjehom u školi. Učenici koji imaju izraženu tu osobinu radoznali su, otvorenog duha i željni novih iskustava u usporedbi s učenicima koji nemaju izraženu navedenu osobinu. Rezultati ovog istraživanja sugeriraju da će učenici koji su znatiželjni i željni novih iskustava i provedbi ideja imati veći interes i motivaciju za učenje (Vrdoljak i sur., 2018).

Na kraju, ugodnost i ekstraverzija nisu pokazale značajnu statističku povezanost s uspjehom u školi u prvoj vremenskoj točki iako su regresijski koeficijenti pokazivali negativni smjer, što je u skladu s prijašnjim istraživanjima. Izostanak statističke značajnosti rezultata može biti uvjetovana malom varijancom (i.e, $\Delta \mathrm{R}^{2}=4 \%$ ) objašnjenom osobinama ličnosti, što može ukazivati na važnost savjesnosti, otvorenosti prema iskustvu i neuroticizmu kod uspjeha u školi, više nego ugodnosti i ekstraverzije koje mogu biti više odlike međuljudskog odnosa nego uspjeha (Chamorro - Premuzic i Furnham, 2005). lako je doprinos od 4\% relativno manji od doprinosa osobina ličnosti prethodnih istraživanja (Ivić i Matešić, 2009; Vrdoljak i sur., 2018), važno je uzeti u obzir i interpretirati njihov značaj za buduća istraživanja. Manji doprinos u ovoj studiji može biti zbog načina mjerenja prediktorskih i zavisnih varijabli. Naime, u ovom istraživanju školski uspjeh mjeren je kao ukupan uspjeh, a ne kao artimetička sredina, i temeljen je na samoiskazima učenika. Isto tako, 76,1\% i 77\% učenika zaokružilo je vrlo dobar i odličan uspjeh na kraju oba mjerenja. S obzirom na brojne subjektivne značajke na kojima se temelji ispitivanje ove varijable, pouzdanost može biti upitna i svakako bi buduća istraživanja trebala na objektivniji način ispitati opći uspjeh u školi.

Rezultati istraživanja povezanosti osobina ličnosti petofaktorskog modela ličnosti te uspjeha u školi u drugoj vremenskoj točki nisu pokazali statističku značajnost, što je u skladu s prijašnjim istraživanjima mjerenim u dvjema vremenskim točkama (Peterson i Whiteman, 2007; Caprara i sur., 2011). Navedene studije pokazale su važnost uloge osobina ličnosti u školskom uspjehu u nižim razredima srednje škole u usporedbi s višim razredima srednje škole, gdje se uspjeh u školi više temeljio na iskustvu i razvijenim vještinama za učenje (Peterson i Whiteman, 2007; Caprara i sur., 2011).

Rezultati povezanosti osobina ličnosti i vladanja u prvoj i u drugoj vremenskoj točki nisu pokazali značajnu statističku povezanost nijedne od dimenzija petofaktorskog modela ličnosti i vladanja. Ocjene iz vladanja izrečene su na temelju broja neopravdanih sati. U uzorku ovog 
istraživanja $86 \%$ ispitanika u prvoj točki mjerenja te 82,4 \% ispitanika u drugoj točki mjerenja imalo je izrečenu najvišu ocjenu vladanja, i to u drugom mjerenju učenici su imali prosječno višu ocjenu vladanja nego u prvom mjerenju. Izostanak povezanosti vladanja i osobina ličnosti može sugerirati na subjektivnu ulogu u načinu ocjenjivanja vladanja u ovom uzorku i na manje stroge kriterije pisanja neopravdanih sati $i$,,gledanja kroz prste" u višim razredima srednje škole. Isto tako, može ukazivati na različite kriterije ocjenjivanja u različitim školama koji nisu nužno povezani s osobinama ličnosti. U ovom uzorku 81,9 \% gimnazijalaca postiglo je najvišu ocjenu vladanja u prvoj vremenskoj točki u usporedbi sa 86,8 \% učenika strukovnih škola; dok je u drugoj vremenskoj točki 70,8\% gimnazijalaca postiglo najvišu ocjenu u usporedbi sa $84,8 \%$ učenika strukovnih škola.

Dodatnim ispitivanjem razlike između uspjeha u školi i vladanja učenika strukovnih škola i gimnazija u ovom uzorku utvrđen je izostanak značajne razlike između uspjeha u školi i vladanja učenika strukovnih škola i gimnazija u prvoj vremenskoj točki te uspjeha u školi učenika strukovnih škola i gimnazija u drugoj vremenskoj točki. Razlika ocjene vladanja učenika strukovnih škola i gimnazija u drugoj vremenskoj točki pokazala se značajnom i to na način da su učenici strukovnih škola imali veće ocjene vladanja od učenika gimnazija ( $M_{\text {gimnazija }}=4.46$, $M_{\text {strukovna }}=4.75$ ). Različita istraživanja pokazala su slabiji školski uspjeh učenika strukovnih škola u usporedbi s učenicima gimnazija (Roviš i Bezinović, 2011), što je suprotno nalasku ove studije i može se interpretirati potencijalnom subjektivnošću i različitim kriterijima ocjenjivanja u ovom uzorku. Dimenzije ličnosti samo su jedan od faktora koji mogu utjecati na školski uspjeh i vladanje. Dobiveni rezultati ukazuju na potencijalni utjecaj obilježja učitelja kao njihov pristup i način ocjenjivanja na ocjenu školskog uspjeha i vladanja (Barbarović i sur., 2010), što bi uz dimenzije ličnosti bilo zanimljivo ispitati u daljnjim studijama.

Zanimljivo je napomenuti da se povezanost između uspjeha u školi i vladanja pokazala značajnom u oba vremenska mjerenja. lako se radi o korelacijskim koeficijentima, studija je pokazala da učenici koji postižu veći uspjeh u školi imaju veću ocjenu vladanja, što u ovom slučaju znači da imaju manji broj ili nemaju neopravdane izostanke. Ovaj nalaz sukladan je prijašnjim istraživanjem koje je mjerilo povezanost školskog uspjeha i neopravdanih izostanaka u školi i pokazalo negativnu povezanost (Markuš, 2009). Učenici koji su više neopravdano izostajali u školi postizali su lošiji uspjeh. S obzirom na učestalost izostajanja u našim školama, i opravdanih i neopravdanih, daljnja istraživanja trebala bi ispitati jesu li dobre/loše ocjene u školi uzrok dobrih/loših ocjena vladanja i izostanaka ili obrnuto, i kakvi su ocjenjivački kriteriji u pojedinim školama.

Nedostatci studije uključuju upotrebu ocjene općeg uspjeha kao varijable koja obuhvaća prosjek ocjena iz velikog broja različitih predmeta što može umanjiti varijabilitet dobivenih rezultata. Buduća istraživanja bi trebala ispitati povezanost osobina ličnosti i ocjena iz različitih grupa predmeta kao društvenih, prirodnih (Vrdoljak i sur., 2018). Nadalje, s obzirom da se radi o samoiskazima učenika, pitanja o općem uspjehu i vladanju mogu biti socijalno poželjna te bi buduće studije trebale na objektivniji način ispitati ocjene učenika. Isto tako, ocjena vladanja uglavnom se temelji na broju neopravdanih sati, što ne mora biti mjerilo ukupnog vladanja. Stoga bi daljnje studije mogle ispitati ocjenu vladanja u kontekstu ukupnog učeničkog ponašanja od neopravdanih sati do odnosa prema učenicima i učiteljima. Završno, nejasne su psihometrijske karakteristike korištenog adaptiranog upitnika osobina ličnosti pa bi te podatke svakako u daljnjim studijama trebalo detaljnije i jasnije ispitati.

Rezultati sugeriraju profesorima u školama poticanje razvoja vještina točnosti, organiziranosti, postavljanja ciljeva te podržavanja novih ideja i radoznalosti kod učenika u svrhu boljeg školskog uspjeha. Nadalje, prepoznavanje anskioznosti i zabrinutosti kod učenika te pružanje podrške i usmjeravanje učenika od iznimne je važnosti. lako dijelovi ovog istraživanja podupiru nalaske u prijašnjoj literaturi, pojedini su segmenti eksploratorni te služe kao smjernica za daljnja istraživanja odnosa petofaktorskog modela ličnosti i uspjeha u srednjoj školi u više vremenskih točki. 


\section{ZAKLUČAK}

Cilj je istraživanja bio ispitati odnos između osobina ličnosti i roda s uspjehom u školi i vladanjem u dvjema vremenskim točkama, na početku 3. i na kraju 4. razreda srednje škole. Istraživanje je pokazalo razliku roda i uspjeha u školi i vladanja u objema vremenskim točkama. Učenice su u ovom uzorku pokazale bolji uspjeh u školi i vladanju u usporedbi s učenicima i na početku 3. i na kraju 4. razreda srednje škole. Nadalje, istraživanje je pokazalo povezanost dimenzija savjesnosti, otvorenosti prema iskustvu te neuroticizma s uspjehom u srednjoj školi, ali ne s vladanjem u prvoj vremenskoj točki. Isto tako, povezanosti uspjeha u školi i vladanja i dimezija ličnosti nisu bile značajne u drugoj vremenskoj točki. Učenici s izraženom osobinom savjesnosti i otvorenosti prema iskustvu postigli su bolji školski uspjeh, dok su učenici s izraženom osobinom neuroticizma postigli lošiji školski uspjeh na početku 3. razreda. Osobine ličnosti nisu se pokazale kao važni prediktori uspjeha u školi na kraju 4. razreda srednje škole.

\section{LITERATURA}

Ashton, M. C., Lee, K. i Paunonen, S. V. (2002). What is the central feature of extraversion? Social attention versus reward sensitivity. Journal of Personality and Social Psychology, 83, 245-252. doi: 10.1037/0022-3514.83.1.245

Barbarović, T., Burušić, J. i Šakić, M. (2010). Psihosocijalne i obrazovne odrednice školskog uspjeha učenika osnovnih škola: Dosezi dosadašnjih istraživanja, Suvremena psihologija, 13(2), 235-256.

Caprara, G. V., Vecchione, M., Alessandri, G., Gerbino, M. i Barbaranelli, C. (2011). The contribution of personality traits and self-efficacy beliefs to academic achievement: A longitudinal study, British Journal of Educational Psychology, 81, 78-96. doi: 10.1348/2044-8279.002004

Chamorro-Premuzic, T. (2007). Personality and Individual Differences. Maidem, Oxford, Carlston: Blackwell Publishing.

Chamorro-Premuzic, T. i Furnham, A. (2003). Personality predicts academic performance: Evidence from two longitudinal university samples. Journal of Research in Personality, 37(4), 319-338.

Chamorro - Premuzic, T. i Furnham, A. (2005). Personality and intellectual Competence. London: Lawrence Erlbaum Associates.

Čuljak, Z. i Mlačić, B. (2014). The big-five model of personality and the success of high school students in physical education. Croatian Journal of Education, 16(2), 471-490.

Čuljak, Z., Markota, M. i Kovačević, A. (2010). Utjecaj motoričkih sposobnosti te motivacije i osobina ličnosti na uspješnost realizacije nastavnog programa sportske gimnastike. U: Andrijašević, M. i Jurakić, D. (ur.), Kineziološki sadržaji i društveni život mladih. Zagreb: Kineziološki fakultet, Sveučilište u Zagrebu.

Efendić-Spahić, T. i Vardo, E. (2017). Osobine ličnosti kao prediktori akademskog sagorijevanja studenata. U: Gavrić, M. i Sesar, K. (ur.), Zbornik radova sa naučnog-stručnog skupa IV. Kongresa psihologa BIH sa međunarodnim učešćem održanim (str. 9-23). Banja Luka: Društvo psihologa Republike Srpske.

Gračanin, A., Kardum, I. i Kapić, N. (2004). Odnos pridjevske i upitničke mjere dimenzija petofaktorskog modela ličnosti. Psihologijske teme, 13(1), 33-46.

Ivić, J. i Matešić, K. (2009). Povezanost inteligencije i nekih osobina ličnosti iz modela „Velikih pet” sa školskim uspjehom u završnim razredima srednje škole. Pedagogijska istraživanja, 6(1-2), 91101.

John, O.P. (1990). The "Big Five" factor taxonomy: Dimensions of personality in the natural language and in questionnaires. U: Pervin, L.A., (ur.), Handbook of Personality: Theory and Research, (str. 66-100.). Guilford Press, New York.

John, O. P., Donahue, E. M. i Kentle, R. L. (1991). The Big Five Inventory - Versions 4a and 5a. Berkley, CA: University of California, Berkeley, Institute of Personality and Social Research. 
Koludrović, M. i Reić-Ercegovac, I. (2013). Motivacija i školski uspjeh: dobne i spolne razlike u ciljnim orijentacijama. Napredak, 154(4), 493-509.

Larsen, R. J. i Buss, D. M. (2008). Personality psychology: Domains of knowledge about human nature. Boston: McGraw Hill.

Markuš, M. (2009). Psihosocijalne determinante školskih izostanaka. Napredak, 150(2), 154-167.

Matešić, K., Ružić. V. i Matešić, K. Jr. (2009). Odnos između osobina ličnosti mjerenih BFQ upitnikom i školskog uspjeha kod učenika gimnazije. Odgojne znanosti, 11(1), 171-181.

Mlačić, B. (2002). Leksički pristup u psihologiji ličnosti: Pregled taksonomija opisivača osobina ličnosti. Društvena istraživanja, 11(4-5), 553-576.

Pervin, L., Cervone, D. i John, O. (2008). Psihologija ličnosti: Teorije i istraživanja. Zagreb: Školska knjiga.

Peterson, E. R. I Whiteman, M. C. (2007). 'I think I can, I think I can ...': The interrelationships among self-assessed intelligence, self-concept, self-efficacy and the personality trait intellect in university students in Scotland and New Zealand. Personality and Individual Differences, 43, 959-968. doi:10.1016/j.paid.2007.02.019

Poropat, A. E. (2009). A meta-analysis of the five-factor model of personality and academic performance. Psychological Bulletin, 135, 322-338. doi:10.1037/a0014996

Pravilnik o povredama discipline, postupku za utvrđivanje odgovornosti učenika, dužini trajanja pedagoške mjere, njenom ublažavanju, ukidanju i posljedičnom odnosu na ocjenu iz vladanja učenika kao i naknadi učinjene materijalne štete (2014). Službene novine Tuzlanskog kantona, 6, 243-244.

Roviš, D. i Bezinović, P. (2011). Vezanost za školu - analiza privrženosti školi i predanosti školskim obavezama kod srednjoškolaca. Socijologija i prostor, 49, 185-208. doi:10.5673/sip.49.2.4

Seiffge-Krenke, I. (2000). Causal links between stressful events, coping style, and adolescent symptomatology. Journal of Adolescence, 16(3), 285-303.

Vardo, E. i Efendić-Spahić, T. (2016). Relacije osobina ličnosti i tipova profesionalnih interesovanja kod studenata Filozofskog fakulteta. Društvene i humanističke studije, 1(1), 263-268.

Vrdoljak, G., Lovaković, I. i Kurtović, A. (2018). Osobine ličnosti, ciljne orijentacije, i školski uspjeh. Primjenjena psihologija, 11(3), 325-344. doi:10.19090/pp.2018.3.325-344

\title{
The Relation between Big Five Personality Traits and School Achievement in High School Students
}

\begin{abstract}
The purpose of the study was to investigate the relation between Big Five personality traits and high school achievement in two time points; at the beginning of the third grade (T1) and at the end of the fourth grade (T2) of high school. The sample included 421 high school students between 16 and 19 years old. The study used adapted version of Big Five Inventory to assess personality traits. High school achievement was measured via students' grade point average (GPA), and their final behaviour grade that was based on the number of unexcused absences from school. The main analysis included two hierarchical regression analyses conducted in each time point. In both time points, gender showed significant relation with the GPA and final behaviour grade. Specifically, female high school students achieved higher GPA and final behaviour grade comparing to male high school students. Moreover, agreeableness and openness to experience were significant positive predictors of GPA, and neuroticism was a significant negative predictor of GPA in first time point. No personality traits were significantly related to GPA and final behaviour grade in second time point. The results explain the relation between specific personality traits and high school achievement in two time points.
\end{abstract}

Keywords: behaviour, education, grade point average, high school students, personality traits 


\section{Das Verhältnis zwischen den Big Five Persönlichkeitsmerkmalen und Schulleistungen bei Schülern der Oberstufe}

Zusammenfassung: In dieser Studie wurde die Verbindung zwischen den Big Five Persönlichkeitsmerkmalen und Schulleistungen am Anfang der dritten Klasse (T1) und am Ende der vierten Klasse (T2) gemessen. 421 Schüler zwischen 16 und 19 Jahren nahmen an der Studie teil. In der Studie wurde eine abgewandelte Version des Big Five Fragebogens verwendet um die Persönlichkeiten der Teilnehmer zu untersuchen. Die Durchschnittsnoten und die Anzahl der unentschuldigten Schultage eines Schülers wurden verwendet um die Schulleistung zu messen. Es wurden zwei hierarchische Regressionsmodelle zu jedem der zwei Zeitpunkte analysiert. An beiden Zeitpunkten wurde ein signifikanter Zusammenhang zwischen der Durchschnittsnote und Fehlzeiten und dem Geschlecht der Schülerinnen festgestellt. Demzufolge hatten Schülerinnen bessere Noten und weniger Fehltage als Schüler. Außerdem, waren Persönlichkeitszüge wie Verträglichkeit und Offenheit für neue Erfahrungen signifikante positive Prädiktoren für bessere Noten. Dahingegen war Neurotizismus bei der ersten Messung ein negativer Prädiktor für bessere Noten.

Keines der Persönlichkeitsmerkmale hatte einen signifikanten Zusammenhang mit Fehlzeiten bei der zweiten Messung. Diese Resultate zeigen die Zusammenhänge von spezifischen Persönlichkeitsmerkmalen und Schulleitungen am Anfang der dritten Klasse und am Ende der vierten Klasse.

Schlüsselwörter: Bildung, Persönlichkeitsmerkmale, Schulerfolg, Schüler, Verhalten 